\title{
AN ANALYSIS OF TEACHERS' NON-VERBAL COMMUNICATION IN EFL CLASSROOM AT SMP NEGERI 3 BANJAR
}

\author{
I.P. Indrawan ${ }^{1}$, P.K. Nitiasih ${ }^{2}$, K.S. Piscayanti ${ }^{3}$ \\ English Education Department \\ Universitas Pendidikan Ganesha, Singaraja, Bali-Indonesia \\ Jalan Jend. A. Yani 67 Singaraja 81116, Telp. 0362-21541, Fax. 0362-27561 \\ E-mail: iputuindrawan@yahoo.com ${ }^{1}$, titiekjegeg@gmail.com², sonia_pisca@yahoo.com
}

\begin{abstract}
ABSTRAK
Penelitian ini bertujuan untuk, (1) menganalisa jenis-jenis komunikasi non-verbal yang digunakan oleh guru Bahasa Inggris ketika proses belajar dan mengajar, (2) mengungkapkan tentang jenis - jenis komunikasi non-verbal yang mempengaruhi motivasi siswa ketika proses pembelajaran di kelas berlangsung, (3) mengungkapkan tentang kontribusi komunikasi non-verbal dalam pembelajaran Bahasa Inggris. Penelitian ini merupakan penelitian deskritif kualitatif yang dilaksanakan di SMPN 3 Banjar. Data pada penelitian berikut dengan cara rekaman video, penyebaran kuisioner, dan interview. Terdapat dua guru Bahasa Inggris yang diikutsertakan dalam penelitian ini, dan 40 siswa kelas delapan dari kelas yang berbeda. Sebelum analisis data, hasil dari penelitian berikut dianalisa secara deskriptif dengan cara mencari fenomena komunikasi non-verbal guru yang terlihat pada rekaman video, menganalisis hasil interview dan mencari persentase dari hasil kuisioner. Hasil dari analisis data yaitu komunikasi nonverbal guru di SMPN 3 Banjar sudah memenuhi kriteria komunikasi non-verbal yang diusulkan oleh ahli. Terdapat beberapa jenis komunikasi non-verbal guru yang berpengaruh terhadap motivasi siswa yaitu ekspresi wajah, gestur, proxemic (kedekatan), haptic (sentuhan), kontak mata, dan paralanguage. Temuan yang terakhir yaitu, gestur dan paralanguage dianggap sebagai komunikasi non-verbal yang memberikan kontribusi terhadap pembelajaran Bahasa Inggris.
\end{abstract}

Kata kunci: komunikasi non-verbal, motivasi siswa, kelas $E F L$

\begin{abstract}
This study was aimed at (1) analyzing kinds of non-verbal communications used by English teachers during the teaching and learning process, (2) revealing what kinds of teachers' non-verbal communications affect students' motivation during the learning process in the classroom, (3) discussing the contribution of non-verbal communications in English education. This study was a descriptive qualitative study conducted at SMPN 3 Banjar. The data were collected by video recording, questionnaire administration, and interviewing. There were 2 English teachers involved as the subject of this research, and 40 students of eighth grade in different classes were involved. The results of the study indicate teachers' non-verbal communication in SMPN 3 Banjar meets the seventh kinds of non-verbal communication proposed by Burgoon, Buller, and Woodall, (1994) as cited in Birjandi and Nushi (2014). It was also found that there are some kinds of non-verbal communication that affect students' motivation, namely facial expression, body movement, gestures, proxemics (proximity), haptics (touch), eye contact, and paralanguage. Gestures and paralanguage are considered as non-verbal communication that gives contribution to English education.
\end{abstract}

Keywords: non-verbal communication, students'motivation, EFL classroom 


\section{INTRODUCTION}

Classroom management skill is one of the requirements that teachers should have. Parsons, Hinson, \& Sardo-Brown (2003) argue that classroom management is the term that the teacher uses to highlight all of those positive behaviors and decisions the teacher makes to facilitate the learning process. It refers to all those activities that necessary to create and maintain an orderly learning environment such as planning and preparation of materials, organization, decoration of the classroom and certainly the establishment and enforcement of routines and rules..

Communication is an integral part of human life. People communicate in different ways to express their thoughts, feelings, knowledge, skills, and ideas (Butt and Iqbal, 2012: 2). It is normally assumed that communication is identified with speech and sounds. In fact, communication means the combination of verbal and non-verbal transmission of knowledge. In teaching, communication is one major thing that makes students and the teacher gets connected each other, share and give information in two ways, either students to teacher nor teacher to students.

Communication between teachers and students also remains another importance of the existence of non-verbal communication in the classroom, it is to deliver clear instruction to the students. Teachers also should be able to give understandable instruction or explanation to their students, so then students will be easier in understanding the materials or instruction given (Pogue and AhYun, 2006).

Non-verbal communication plays a very significant role during the teaching-learning process in the classroom (Butt \& Shafiq, 2013: 27). Moreover, in learning a foreign language non-verbal communication is very demanding, because non-verbal communication exerts a significant impact on the comprehension of the students which ultimately results in better learning and understanding of the concepts. According to Rosa (2000) as cited in Negi (2009: 103). Research studies done in classroom environments also suggest that nonverbal behaviors to send clear and distinct messages. Moreover, these 'non-verbal messages can be a more explicit and candid means of determining intent than merely the spoken word alone'. It means that non-verbal communication cannot be separated. This statement implies that non-verbal communication as a supporting thing that makes the verbal ones become more understandable whenever it is used in EFL classroom where the students still have inadequate English mastery.

"A foreign language is a language which is not normally used for communication in a particular society" (Tomlinson, 2012). Indonesian people rarely use English for communication. In everyday life they use Bahasa Indonesia to communicate each other. It is rare to see that Indonesian people communicate using English in their daily life. It is different from other countries such as India and Philippine, which use English as a second language, in addition to their national language.

The objective of an EFL classroom interaction is learning a foreign language of which students have little or no command yet (Elfatihi, 2013). That is why nonverbal communication seems to have a reason to exist in the EFL classroom. Teachers use nonverbal communication, especially gestures, either consciously or unconsciously. Nonverbal communication also could support teacher in giving an example, for instance imitating a bird, the teacher can use both of their hands to imitate the movement of the bird.

The goal in using non-verbal communication is to help students to understand what is being explained by the teacher (Bunglowala, and Bunglowala 2015). Some of the students with lack of vocabulary knowledge also can be helped in understanding a word throughout a non-verbal communication, a teacher may use certain gestures to give a clue to their students to guess a word that is intended to tell to their students. As a conclusion, non-verbal communication can be perceived as an important point to support teacher in teaching English, specifically (EFL), where the students use English only for the sake of studying and not even use it as daily communication. 
Teachers' non-verbal communications do count as the source where students' motivation in learning comes. According to Harmer (2007:98), extrinsic motivation is the result of any number of outside factors, and this type of motivation appears from outside and gives some influences to a person like giving incentives, social pressure and punishment. Mostly this type of motivation comes from teacher, parents, and environment, especially from teachers' non-verbal communication.

Empirically, there were several studies that have been conducted concerning in the area of teacher's non-verbal communication in the journal articles of Butt \& Shafiq, (2013) entitled "Significance of Non-verbal Communication in the Teaching-Learning Process", Hsu (2011) entitled "The Impact of Perceived Teachers' Nonverbal Immediacy on Students' Motivation for Learning English", Negi (2009) entitled "The Role of Teachers' non-verbal Communication in ELT Classroom", Behjat, Bahyat, \& Kargar, (2014) entitled "An investigation of students' attitudes on teachers' nonverbal interaction in Iranian EFL classrooms",Karim and Sotoudehnama, (2017) entitled,"A qualitative study on teacher's nonverbal communication and Iranian EFL learners' perception of language learning", and Haneef, Faisal, Alvi, and Zulfiqar (2014) entitled "The role of non-verbal communication in teaching practice". These researchers found that facial expression, eye contact, body movements, the teacher's voice, and the appropriate distance between teacher and the students positively affected the students' motivation, and teaching and learning process. This study was aimed at: first, analyze what kinds of non-verbal communications used by English teacher during the teaching and learning process, second, reveal how teacher's non-verbal communications affect students' motivation during the learning process in the classroom, third to reveal about the contribution of non-verbal communications in English education.

\section{METHODS}

This study was conducted at SMP Negeri 3 Banjar, which is located at Singsing street, Banjar district, Buleleng regency, Bali. The data were collected during teaching and learning process in this school. The design of this present study was a qualitative descriptive study. According to Miles and Huberman (1994), qualitative research is a design and method of data analysis guided by the philosophical assumptions of qualitative inquiry, but this research also used a simple calculation in describing the data. This design was chosen for this present study because this study obtains information concerning the current status of the phenomena to describe the relevancy with respect to variables or conditions in a situation.

The subjects of this study were English teachers and students of the eighth grade in SMP Negeri 3 Banjar, Banjar District, Buleleng Regency. There were 42 subjects including 2 English teachers and 40 students of the eighth grade. The eight grade students were chosen because they were in the middle of the year. In relation to the teachers' non-verbal communication is that they have experienced how teacher utilizes their non-verbal communication in the classroom more than what the seventh grade have, moreover due to the limited of time and the study was conducted in even semester in which the ninth grade already passed their national examination, the researcher could not be able to involve the ninth grade students.

The object of this study was the kinds of teachers' non-verbal communications that used by the teacher and occurred in the English classroom at seventh and eighth grades in SMPN 3 Banjar. The researcher chose teachers' non-verbal communications as an object of the study because based on what the researcher has been observed, teachers' non-verbal communications has a small attention as an object of a study. Therefore this study conducted In order to be able to shed the light of the contribution of teachers' non-verbal communication in teaching and learning process 
Prior to the data collection, there were three methods of data collection used in this study namely, video recording, questionnaire administration, and interviewing. In Video recording, the researcher recorded the teaching and learning process to able to gain the data that shows about teachers' non-verbal communication used by the English teacher during the teaching and learning process. In questionnaire administration, it was done in this study in order to be able to find what kinds of teachers' non-verbal communication that affect student motivation in learning, In Interviewing in this study, interviewing was used in order to be able to gain the data that correspond to the research question that aimed to find out what is the contribution of non-verbal communication in English education.

The main instrument in this research was the researcher himself. In this study, there were three instruments used namely, Video recording device, questionnaire, and voice recording device. (1) Video recording device used to record the teacher during their teaching and learning process in the classroom the researcher recorded the teaching and learning process. (2) Questionnaire administration was conducted in this study in order to be able to find what kinds of teachers' non-verbal communication that affect student motivation in learning. (3) Voice recording device used to record the conversation between the researcher and the interviewee during the interview sessions.

Conducting a research needed some steps. The researcher came to the field in SMP Negeri 3 Banjar to conduct the video recording in the classroom, there were two English teachers Mrs. Asitanti, and Mr. Yardaka whom the researcher has recorded during their teaching sessions in the classroom, the recording conducted for three times for each of the teachers. Before the video recording was conducted the researcher make an appointment and scheduled the video recording session due to the teachers taught different grades. Then questionnaire administration was conducted in the classroom, there were two classes of eighth-grade students involved in question- naire administration. The researcher gave 30 minutes for the students to fill or answer the questionnaire. The last was conducting interviews with the teacher that have been recorded during the teaching and learning process before the interviews were conducted the researcher set the appointment with the teachers. There was six question asked to both of the teachers that aims to find out what is the contribution of teachers' non-verbal communication that gives contribution in English education.

After all of the data were collected, then the researcher analyzed the data from video recording following the criteria of non-verbal communication proposed by Burgoon, Buller, and Woodall, (1994) there were 7 kinds of nonverbal communication namely, kinesics, proxemics, oculesics, chronemics, paralanguage and, posture. Then the researcher capture every single non-verbal communication appeared in the video then presented it descriptively in the finding. Then the administered questionnaires computed by using Microsoft Excel in order to be able to find the percentage of each item given in the questionnaire then the result of the analysis displayed descriptively to answer the research question about teachers' non-verbal communication that affects students' motivation. The last was analyzing data from the interview. The researcher firstly transcribed the result of the interview in order to be able to display the necessary data that correspond to the research question 3 .

Triangulation technique was used in this study in order to verify the data. Triangulation was used to confirm the findings. Therefore, this assured the concept of triangulation in collecting the data to make the data were valid and reliable. In this study, the researcher followed methodological triangulation. Methodological triangulation refers to the use of multiple methods to study a situation or phenomenon. The aim was to decrease the deficiencies and biases that come from any single method. In other words, the strength of one method may compensate for the weakness of another (Denzin, 2010: 15). 


\section{FINDINGS AND DISCUSSION}

\section{Non-verbal communication used by the teacher at SMPN 3 Banjar}

\section{Kinesics}

Kinesics is divided into three different focuses those are body movements, facial expressions, and gestures.

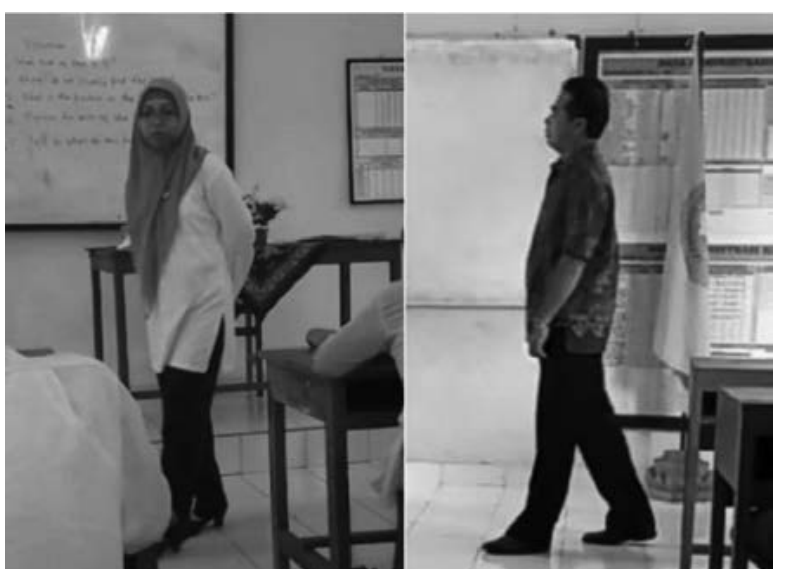

Picture 1. Teachers' Body Movement in the classroom

The teacher in the class is more likely to be active as indicated by their body movement. There were enthusiastic and welcome to teach the students. In the above picture 4.1, it can be seen that Mrs. Asitanti and Mr. Yardaka moved their feet to move around in the classroom while monitoring their students instead of just standing in front of the class.

\section{Facial Expression}

The smile is the most frequent one used by both of the teachers. Both of the teachers use smile whenever they appreciate the students' work, in humorous situations, or whenever the class has an uncomfortable atmosphere, the smile can alter sad feelings into happiness as well as boredom. implicitly smile can also strengthen students' motivation, and their confidence to talk with their teachers. As seen in the above picture, Mrs. Asitanti gives her smile to the students whom she talks with, as well as Mr. Yardaka also often smiling to his students during the lesson.

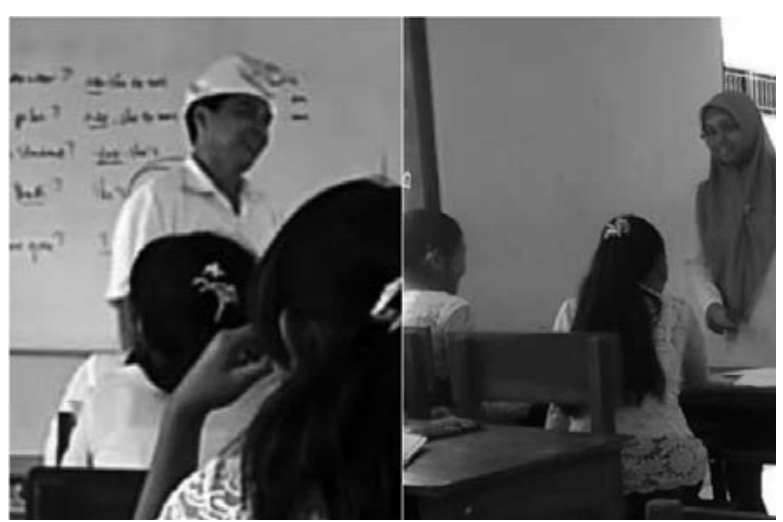

Picture 2. Teachers' Facial expression in the classroom

\section{Gesture}

The gesture was the second kind of non-verbal communication used by both of the teachers during teaching and learning process. There are several kinds of gestures used by both teachers, as seen in the above pictures 4.3, Mrs. Asitanti and Mr. Yardaka open their palms to point at some students to point out their opinion toward the lesson given. Gestures are mainly used by both of the teachers in describing or saying something to their students. Moreover for Mr. Yardaka, who teaches the seventh grade in which most of the students have inadequate levels of English especially in vocabulary.

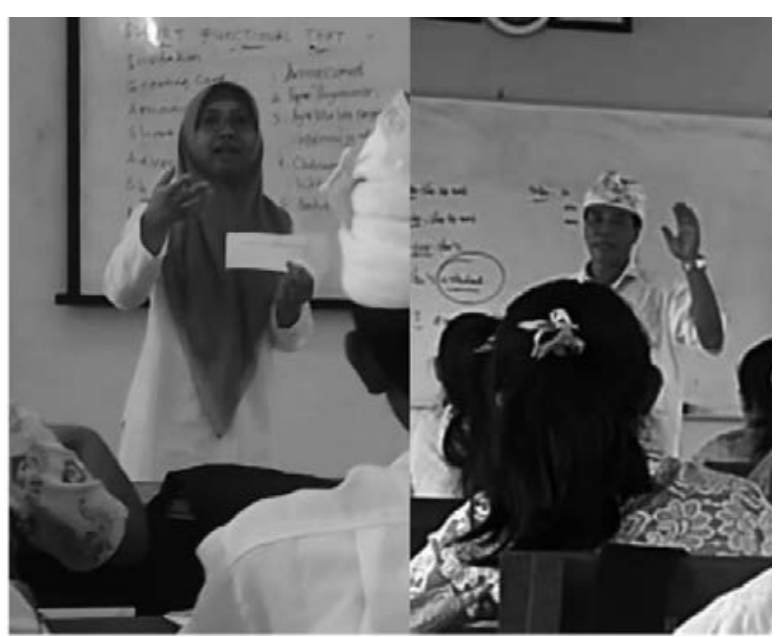

Picture 3. Teachers' gestures in the classroom

\section{Proxemics}

The use of space in the classroom can have a major impact on communication. Both of the teachers frequently went forward, approaching the students during teaching and 
learning process. Somehow, in every classroom at SMPN 3 Banjar still applying the traditional seating arrangement in which students have a well-arranged seating and table, then the teacher stands right in front of them. The impact of this traditional seating arrangement that, the students who sit in the front row are more likely got more intense interaction with the teacher. Meanwhile, the students who sit at the back are more likely got less attention. Based on the recording both teachers already implemented proxemics maintain their distance to the students while teaching to maintain the communication as a boredom preventer.

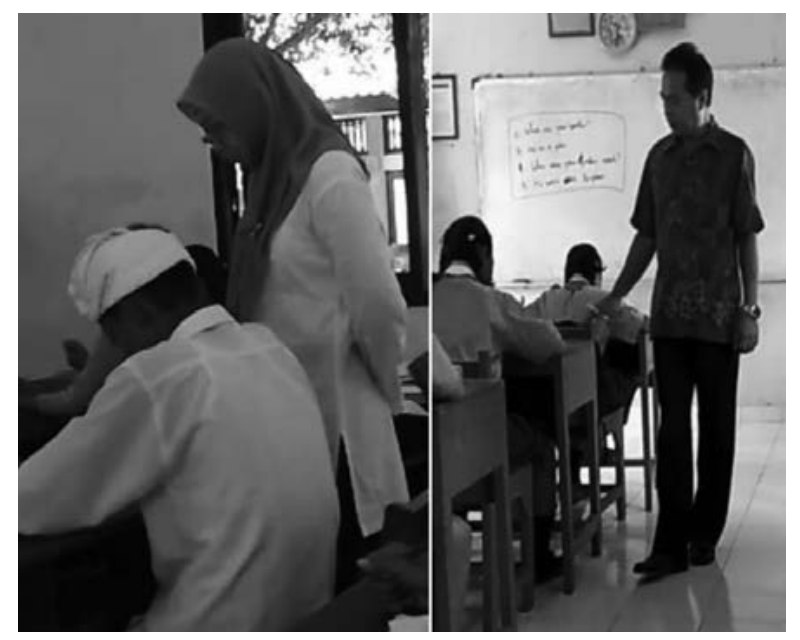

Picture 4. Teachers' proximity with the students in the classroom

\section{Haptics}

Haptics in teaching and learning process are rarely used. As seen on the video, Mrs. Asitanti, the one who teaches the eighth grade used haptics in order to motivate her student to be brave to come in front of the class. At that time she was inviting some students to mention about a functional text, but no one was dared to come in front of the class so she invited a male student who seemingly knows the answer and he was a bit shy to come in front of the class. As seen on the above picture 4.5 Mrs. Asitanti trying to convince a male student to come in front of the classroom to present his work In the other hand, Mr. Yardaka didn't show any haptics behavior during the teach- ing and learning process, in the whole video recording he didn't show any haptics behavior because of that this kind of non-verbal communication that rarely used by the teacher at SMP N 3 Banjar.

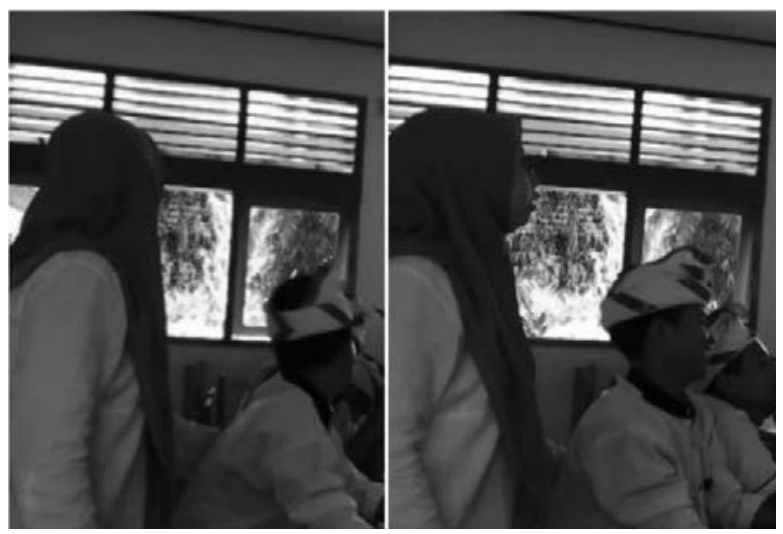

Picture 5. Teacher touching student's shoulder in the classroom

\section{Eye contact}

One of the most important parts of nonverbal communication is eye contact between teacher and the students. It strengthens the verbal communication between teachers and their students, moreover, in teaching and learning process where the teacher has the role as the source person. Meaning that teacher should be able to attract students' attention. Based on the recording, both of the teachers had already implemented eye contact or eye gaze in their teaching and learning process. They regularly looked at their students while teaching, as seen in the above pictures 4.6 both of the teachers were making an eye contact with the students

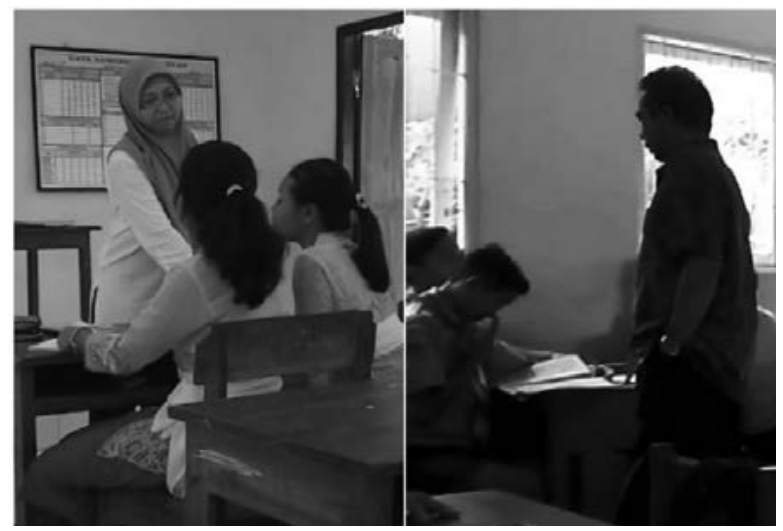

Picture 6. Teachers' eye contacts in the classroom 
in the classroom during the lesson, both teachers' and the students' were having an eye contact while communicating, both of the teachers were looked more enthusiastic whenever they were talking with the students enjoyable with the constant eye contact.

\section{Chronemics}

Time is one of the crucial parts when it deals with teaching and learning process. Based on the video, both of the teachers are a more likely punctual person. Meaning that they started and ended the classroom session on time just like what had been scheduled by the school. During teaching and learning activity, there are some parts that need time management those are beginning, middle, and ending. Based on the recording of both teachers those three aspects of teaching and learning activity had the same portion of time allotment meaning that the beginning, middle, and ending activity had the equal portion of the time. While giving the students an assignment in the classroom, both of the teachers also seem to be strict about giving the time allotted for the student to finish their work.

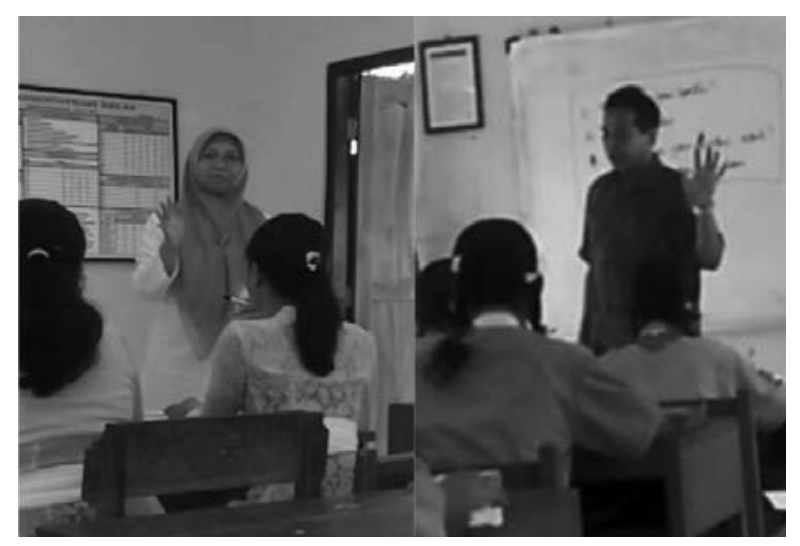

Picture 7. Teacher giving time allotment for the students

\section{Paralanguage}

Vocal cues include intonation, voice quality, and vocal emphasis and that can enhance verbal meaning. As seen on the recording both of the teachers sometimes use vocal cues in a different situation. Sometimes both of the teachers give an emphasis on their voice to give a clear or important information to their students. For example "listen up everyone, there are several kinds of short functional text those are: greeting card, announcement, advertisement and etc." the emphasis added to the main content which is important, in this case, the emphasis added to the kinds of short functional texts.

\section{Posture}

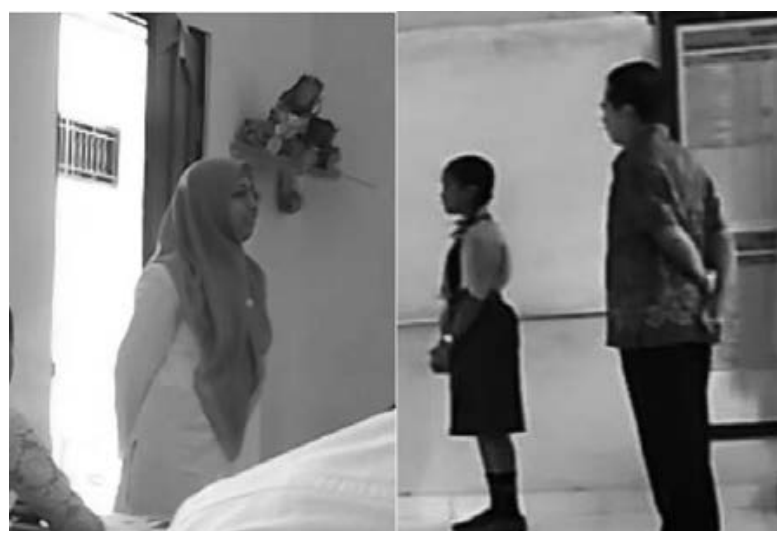

Picture 8 . Teachers' Posture in the classroom

Posture helps communicate a message of self-confidence, awareness, and enthusiasm. As seen in the video, both of the teachers Mr. Yardaka and Mrs. Asitanti had already shown their posture during teaching. They looked more attractive with their good posture, stand tall with proud. From their posture, it can be perceived that they were ready to teach the students enthusiastically. Posture gives the students the impression about their teacher, imagine if a teacher has a bad posture it will impact students' perception about their teacher. Teacher's posture can also influence the classroom atmosphere, whenever a teacher looks not enthusiastic or can be said looking unhealthy the students are more likely bored seeing the teacher who did not teach them well.

\section{Kinds of Non-verbal communication that affects students' motivation}

As seen on table 4.1 it can be discussed that $67.5 \%$ out of 40 students strongly agreed and $32.5 \%$ out of 40 students agreed with the statement that says "teacher that often smiling teaches more effectively rather than the 
teacher who teaches seriously in the classroom. Seemingly with statement number 19 which states "I feel really enthusiastic whenever I got the lesson with the teacher who easily gives smile during the teaching and learning process" and the response is $80 \%$ out of 40 students strongly agreed and $17.5 \%$ out of 40 students agreed with this statement. From this result, it can be inferred that students were highly motivated with the teacher that usually showing a smile on their face.

In the third statement which states that "I feel nervous whenever the teacher pointing at some students to give some question" $15 \%$ out of 40 students strongly agreed and $57 \%$ out of 40 students agreed this statement, from this result it can be inferred that most of the students feel demotivated and anxious whenever the teacher points at the students randomly and give them some questions to be answered. Still in the part of teacher gesture which represented through statement number 7,'I feel more enthusiastic whenever the teacher give an appreciation such as thumb up after I come in front of the classroom". $70 \%$ of 40 students responded strongly agreed and 30\% from 40 students responded agreed with this statement, thumbs ups is relatable as a simple thing during teaching and learning process, On the body movement part, which implicitly stated in statement number 11, "I like teachers who always walks around the classroom during the lesson and it make me stay active during the lesson" and the response for this statement is $25 \%$ students strongly agreed and $60 \%$ students agreed with this statement.

Haptics (touch) represented through item number 12 with the statement that says "I feel confident to come in front of the classroom after the teacher pat my shoulder gently" $40 \%$ students strongly agreed and $57 \%$ students agreed with the statement, from the result above, it can be inferred that students can easily be motivated and gain their confidence after given a pat on their shoulder from the teacher.

Based on the above finding it can be concluded that there are several kinds of teachers' non-verbal communication that could make students feel motivated as well as demotivated. Along with the above finding of kinds of non-verbal communication that affect student's motivation, there are kinesics, especially teachers' smile, gestures and body movement can make students highly motivated in learning, as well as the other kinds of teachers' non-verbal communication that stated above.

\section{Non-verbal communication in English edu- cation}

By using hand movement teacher could demonstrate some kinds of new vocabularies that students never heard before, as seen on the recording Mrs. Asitanti were teaching short functional text, and she used her hands to illustrate a small box by using both of her hands to make the student guess what she intended to say to the student. Paralanguage, the tone, stress, pitch, and the loudness of teachers' voice also give an impact to the clarity of the words that uttered by the teacher, as well as the way to pronounce a word. Junior high school students tend to have still less knowledge about English.

\section{Discussion}

Based on what has been stated in the findings, both of the teachers frequently used body movement during the lesson, as well as facial expression and gestures gave the same quantity of usage by the teacher during teaching. This statement supported Richmond, McCrosky and Hickson's statement (2007) that, students from kindergarten to graduate school respond better to teachers who smile. The smile is one to the keys of a better teacher-student relationship it makes the students become less anxious during the teaching and learning process. Additionally, according to Najarsadegan and Dabaghi (2014: 114) state that gestures that are regulators greatly aid in understanding a speaker's message as they supply extra clues for determining the meaning of an utterance. This statement supports that facial expressions and gestures is an initial part of non-verbal communication and is required in English teaching and learning. Mrs. Asitanti, 
and Mr.Yardaka seen regularly approached their students during the lesson. As what has been observed and seen on the recording they approached their students in order to be able to observe the students during the lesson whether they are making progress or not during the lesson. In line with Butt \& Shafiq (2013: 31) state that appropriate distance between teachers and students is necessary for the proper learning of the students and acceptable distance in the classroom was found very conducive to the learning environment.

Touching was rarely used by both of the teachers during the lesson, however, Mrs. Asitanti caught on the recording using this kind of non-verbal communication to her student, and she gave her student a pat on the shoulder of her student, in order to persuade her students to be brave to come in front of the classroom. According to Najarsadegan \& Dabaghi (2014: 115) state that by using haptics as another form of non-verbal behavior could remove students' stress, for instance, in the exam session, a reassuring pat on the learner's back can relax them and help them recall what they learned.

Mr.Yardaka didn't seem to use any touching during the teaching and learning process this phenomenon happened due to haptics can be threatening because of its connection to sex and violence (Hans and Hans, 2015: 48). Teachers need to always use their best judgment as to whether or when to use touch in communicating with their students (Mobaraki, 2014:43) the other reasons that prove Mr. Yardaka didn't use any touching during his teaching and learning process because he might think that during all of the teaching and learning process that has been recorded he didn't need to use haptics because it was not necessary.

Eye contact was the most frequent ones used by the both of the teachers during the lesson, both of the teachers seen repeatedly used eye contact while communicating with their students during the lesson, In line with this finding, According to Negi (2009: 107) state that students become more active if the teacher kept movements in the classroom and made frequent eye contacts with them. In line with this statement Behjat, Bahyat, \& Kargar (2014: 17) state that teachers make the learning environment active through their eye contact and students feel alert and take active participation in the classroom. Both of the statement supports the finding of this research that eye contact could take students attention and make the classroom become more alive.

Chronemics or the way people use time and react to time showed by both of the teachers during the lesson. Chronemics also can be shown by the punctuality of the teacher, as stated in the finding both of the teacher tend to be punctual in coming in the classroom as well as ends the classroom session. This finding supported by the statement of Najarsadegan \& Dabaghi (2014: 116) that says punctual teachers tend to have punctual students, being on time prevents learners from distraction. Posture is the last part of non-verbal communication that used frequently by the teacher, both of the teacher shows a good posture during the lesson, both of them always stand erect in front of the classroom, they regularly did it during the lesson. This statement is in line with the statement of Najarsadegan \& Dabaghi (2014: 116) that says the teacher should have a relaxed posture, slump posture is a sign of either low self- confidence or lack of knowledge while stiff posture is a sign of pride and feeling superior.

Based on the above finding, facial expression, body movement, gestures, proxemics (proximity), haptics (touch), eye contact, and paralanguage of the teacher positively affect students' motivation and the teaching and learning process. These findings are in line with some empirical studies that conducted earlier, and reported in introduction and empirical review, in the journal of Butt \& Shafiq (2013), Hsu (2011), Negi (2009), Behjat, Bahyat, \& Kargar (2014), Karim \& Sotoudehnama (2014), Akinola (2015) and Haneef, Faisal, Alvi, \& Zulfiqar (2014).

In this study, the researcher found the contribution of non-verbal communication in English education namely gestures and paralanguage. Teachers' gesture helps students in 
learning new vocabulary. This finding supported by a similar study that has been conducted by Karim \& Sotoudehnama (2017) "with the average age of sixteen stated that they observed hand gestures as the most useful aspect of non-verbal communication specifically in vocabulary learning". teachers' paralanguage give contribution in English education because through teachers' paralanguage help the students in pronouncing a word, uttering a sentence in the right rising and falling tone. This finding also supported by a study conducted by Sotoudehnama (2017) students mentioned that they learn the way to pronounce a new word that they have never heard from their teachers, and by this evidence teachers' voice also help students in learning to pronounce a new vocabulary.

\section{CONCLUSION AND SUGGESTION}

Based on the findings of this research, it can be concluded that teachers in SMPN 3 Banjar already fulfill the criteria kinds of nonverbal communication proposed by Burgoon, Buller, \& Woodall, (1994). There are 7 kinds of non-verbal communication that used by both of the teacher Mr. Yardaka and Mrs. Asitanti, those are Kinesics, proxemics (proximity), haptics (touch), eye contacts, chronemics (time), paralanguage, and posture.

Facial expression, body movement, gestures, proxemics (proximity), haptics (touch), eye contact, and paralanguage of the teacher positively affect students' motivation and the teaching and learning process. This findings are in line with some empirical studies, in the journal of Butt \& Shafiq's study (2013), Hsu's study (2011), Negi's study (2009), Behjat, Bahyat, \& Kargar's study (2014), Karim and Sotoudehnama's study (2014), Akinola's study (2015) Haneef, Faisal, Alvi, and Zulfiqar's study (2014) which have the same findings, that facial expression, eye contact, body movements, the teacher's voice, and the appropriate distance between teacher and the students positively affected the students' motivation, and teaching and learning process. Teachers' gesture and paralanguage are the kinds of the non-verbal channels that give contribution in English education, Students' motivation is an important factor that can keep them learning new things. Therefore teacher should aware about utilizing their non-verbal communication, because some kind of teachers' non-verbal communication, can positively affect students motivation during the lesson.

\section{REFERENCES}

Akinola, o. A. 2014. The Use Of NonVerbal Communication In The Teaching Of English Language. Journal of Advances in Linguistics, $4(3)$.

Argyle, M. 2013. Bodily Communication. London, Great Britain: Routledge.

Behjat, F., Bayat, S., \& Kargar, A. A. 2014, November 18. An Investigation Of Students'Attitudes On Teachers'Non Verbal Communication. International Journal of Language and Linguistics, 2 (Special Issue: Innovations in Foreign Language Teaching.), 13-18. doi:10.11648/j.ij11.s.2014020601.13 Birjandi, P., \& Nushi, M. 2010. Non-Verbal Communication in Models of Communicative Competence and L2 Teachers'. Journal Of English Studies, 4-22.

Brown, H. 2007. Principles of Language Learning and Teaching (Fifth ed.). A Pearson Education Company.

Bunglowala, A., \& Bunglowala, A. 2015. Nonverbal Communication: An Integral Part Of Teaching Learning Process. International Journal of Research in Advent Technology (Special Issue 1st International Conference on Advent Trends in Engineering, Science and Technology “ICATEST 2015”), 371-375.

Butt, M. N., \& Shafiq, M. 2013. Significance of Non-Verbal Communication in The Teaching-Learning Process. FWU Journal of Social Sciences, 7, 1- 27.

Denzin, N. 2010. An Introduction to Triangulation. Switzerland : UNAIDS.

Diane Mavers. 2012. Transcribing video. NCRM MODE Working Paper, 1-19.

Ekol, G. L. 2010. Educational Communication. Creative Commons. 
Elfatihi, M. 2006, May 13. The Role of Non-verbal Communication in Beginners' EFL Classrooms: Sale Junior High Schools as a Case. Online Submission, 43.

Gilakjani, A. P. 2012. A Study Of Factors Affecting Efl Learners' English Pronunciation Learning And The Strategies For Instruction. International Journal of Humanities and Social Science, 119-128.

Hans, A., \& Hans, E. 2015. Kinesics, Haptics and Proxemics Aspects of Non-Verbal Communication. IOSR Journal of Humanities and Social Science (IOSR-JHSS), 20(2), 47-52.

Hanafiah, N. 2010. Konsep Strategi Pembelajaran. Bandung: Rafika Aditama.

Haneef, M., Faisal, M. A., Alvi, A. K., \& Zulfiqar, M. 2014. The Role Of Non-Verbal Communication In Teaching Practice. Science International, 26(1).

Harmer, J . 2001. The Practice of English Language Teaching Third edition. Longman Pearson.

Huang, L. 2011, July 4. Nonverbal Communication in College English. Journal of Language Teaching and Research, Vol.2, 903908. doi:10.4304/j1tr.2.4.903-908

Knapp, M. L., Hall, J. A., \& Horgan, T. G. 2013. Nonverbal Communication in Human Interaction. Boston, USA: Cencage Learning.

Lisa Hsu. 2011. The Impact Of Perceived TeachErs' Nonverbal Immediacy On Students' Motivation for Learning English. Asian EFL Journal.

Marzano, R. J., Marzano, J. S., \& Pickering, D. 2003. Classroom Management That Works: Research-Based Strategies for Every Teacher. Virgina, USA: ASCD.

Miles, M. B., \& Huberman, A. M. 1994. Qualitative Data Analysis: An Expanded Sourcebook. Thousand Oaks, California, America: SAGE Publications.

Mobaraki, M. 2014. English Language Teachers' methods Of Using Nonverbal Communication. Doctoral dissertation, University of Birjand

Najarzadegan, S., \& Dabaghi, A. 2014. Effective Nonverbal Communications and English Language Classrooms. IJRELT, 2, 110 - 118.

Negi, J. S. 2009, December. The Role of Teach-
ers'Non-Verbal Communication in ELT Classroom. Journal of NELTA, Vol.14, 101-110. doi:10.3126/nelta.v14i1.3096

Pintrich, P. R., \&Date. H. Schunk. 2008. Motivation in Education Theory, Research and Application. New Jersey : Pearson Education.

Pogue, L. L. and AhYun, K. 2006, Febuary 03.

The Effect of Teacher Non-verbal Immediacy and Credibility on Student Motivation and Affective Learning. Journal Communication Education, Volume 55 (Issue 3), 331-344. doi:10.1080/03634520600748623

Purwanto, N. 2011. Psikologi pendidikan. Bandung: PT. Remaja Rosda Karya Offset.

Richmond, V. P., \& McCroskey, J. C. , \& Hickson, M. L. 2007. Nonverbal Behavior in In terpersonal Relations (6th ed.). Boston, MA: Allyn and Bacon.

Ryan, R. M., \& Deci, E. L. 2000. Intrinsic and extrinsic motivations: Classic definitions and new directions. Contemporary educational psychology, 25(1), 54-67.

Santrock, J.W. 2004. Psychology by Santrock. McGrow-Hill.

Schmitz, A. 2012. A Primer on Communication Studies. California: Creative commons.

Sotoudehnama, E. 2017. A Qualitative Study on Teacher's Nonverbal Communication and Iranian EFL Learners' Perception of Language Learning. Language Horizons, 1(1), 109-133 doi: 10.22051.

Sutiyatno, S. 2015. The Role Of Nonverbal Communication In English Teaching. Transformasi Jurnal Informasi \& Pengembangan Iptek, 11, 27-32.

Yilmaz, K. 2013. Comparison of Quantitative and Qualitative Research Traditions: Epistemological, Theoretical, and Methodological Differences. European Journal of Education, 48(2), 311-325. 